\title{
Use of Microsoft Teams and Youtube in the Application of E-Learning to Improve Student Learning Outcomes in Three-Dimensional Material
}

\author{
Wahyoe Sugiarto \\ SMA Negeri 1 Jepara \\ omwahyoe@gmail.com
}

Received: November 2020; Accepted: December 2020; Published: January 2021

\begin{abstract}
The objectives of this study were (1) to increase the motivation to learn the mathematics of students of XII MIPA-2 with three-dimensional material through the application of E-learning using Microsoft Teams and Youtube, (2) to increase the mathematics learning achievement of students of XII MIPA-2 with three-dimensional material through the application of E-learning using Microsoft Teams and YouTube. The method used is classroom action research. Data collection through tests and non-tests. The test technique is to determine learning achievement using the items while the non-test technique is to determine the development of learning motivation using observation sheets. Data analysis used comparative descriptive for learning achievement data and qualitative descriptive for learning motivation data. The results of this classroom action research showed that the students 'motivation to learn mathematics increased from low to high and the average score of students' mathematics learning achievement increased by $20.85 \%$ from 65.05 to 78.61 with an increase in completeness level of $57.88 \%$, namely from 52, $78 \%$ to $83.33 \%$, so theoretically and empirically through the application of E-learning using the Microsoft Teams and Youtube application it can improve the results of motivation and achievement in learning mathematics in three-dimensional material for students of class XII MIPA-2 SMA Negeri 1 Jepara in the odd semester of $2020-2021$.
\end{abstract}

Keywords: e-learning, microsoft teams, youtube, three dimensions.

How to cite: Sugiarto, W. (2021). Use of Microsoft Teams and Youtube in the Application of E-Learning to Improve Student Learning Outcomes in Three-Dimensional Material. Journal of Medives: Journal of Mathematics Education IKIP Veteran Semarang, 5(1), 129-136. 


\section{PENDAHULUAN}

Kondisi pandemi Covid-19 yang telah berlangsung sejak awal tahun 2020 ini sangat berdampak luas di seluruh dunia. Tidak hanya dalam bidang politik, kesehatan, dan ekonomi, namun juga berdampak pada jalannya proses pendidikan disekolah formal. Oleh karena itu pada 9 Maret 2020 Menteri Pendidikan dan Kebudayaan (Mendikbud) Nadiem Makarim mengeluarkan surat edaran untuk pencegahan virus corona (Covid-19) pada satuan pendidikan. Setidaknya sudah ada dua surat edaran yang dikeluarkan yaitu Surat Edaran Nomor 2 Tahun 2020 tentang pencegahan dan penanganan Covid-19 di lingkungan Kemendikbud dan Surat Edaran Nomor 3 Tahun 2020 tentang pencegahan Covid-19 pada satuan pendidikan. Kegiatan sekolah pun berlangsung tidak seperti tahun-tahun sebelumnya, saat situasi sebelum pandemi virus corona. Pemerintah melalui Kemendikbud memindahkan ruang belajar ke dunia maya dengan program bernama Pembelajaran Jarak Jauh (PJJ). Semua tingkat pendidikan formal mulai dari PAUD/TK hingga Perguruan Tinggi wajib melakukan PJJ termasuk pembelajaran matematika di SMA.

Di sisi lain kita semua tahu bahwa matematika merupakan dasar dari berbagai ilmu pengetahuan, oleh karena itu pembelajaran matematika harus dapat memberikan pemahaman yang lebih dari sekedar menghafal rumus-rumus yang ada. Secara umum hasil belajar matematika siswa di Indonesia sangat memprihatinkan jika dibandingkan dengan negara-negara lain. Sebanyak
77\% siswa Indonesia memiliki pencapaian hasil belajar matematika yang rendah (Tanaka, 2012). Lebih lanjut ia mengatakan rendahnya pencapaian hasil belajar matematika siswa Indonesia disebabkan salah satunya adalah kurangnya pemahaman siswa akan konsep dasar dan pengetahuan dasar ketika pembelajaran berlangsung. Ditambah adanya kondisi pandemi yang mewajibkan sekolah melakukan PJJ akan menimbulkan masalah baru. Salah satu kelas yang peneliti ampu yaitu XII MIPA-2. Kelas XII MIPA-2 cukup aktif ketika pembelajaran tatap muka, namun pengalaman peneliti ketika di awal masa pandemi keaktifan secara klasikal menurun. Dari 36 siswa hanya 20 siswa saja (atau 55,55\%) yang aktif dalam mengikuti PJJ, sisanya sebanyak 44,45\% siswa mengikuti PJJ sekedar absen dan tidak mengikuti pembelajaran hingga selesai. Hal ini berakibat pada prestasi belajar siswa yang menunjukkan bahwa hanya $52,78 \%$ saja yang mampu mencapai Kriteria Ketuntasan Minimal (KKM) yang ditentukan untuk mata pelajaran matematika yaitu 70. Rata-rata prestasi belajar siswa hanya mencapai 65,05 dengan nilai tertinggi 100 dan nilai terendah 40. Sangat jauh rentang nilai antara tertinggi dengan terendah.

Guru sebagai garda terdepan dalam dunia pendidikan dituntut untuk terus berinovasi agar cakupan kurikulum nasional tetap bisa terlaksana dengan baik. Untuk mendukung hal itu, peneliti berinisiatif melaksanakan pembelajaran online (e-learning) dengan menggunakan aplikasi Microsoft Teams dengan kombinasi aplikasi Youtube. Peneliti yakin dengan kelengkapan fitur dan 
kemudahan akses yang dimiliki dua aplikasi ini dapat mendukung proses PJJ dengan lebih efektif. Pembelajaran di kelas yang peneliti ampu yang notabene sangat bergantung pada kehadiran guru disetiap pembelajaran dapat terwakili dengan baik. Peneliti berharap siswa XII MIPA-2 khususnya pada materi dimensi tiga dapat lebih aktif dan meningkat prestasi belajarnya. Setidaknya jumlah siswa yang mendapat nilai di atas tuntas (di atas 70 ) mencapai $75 \%$ dengan nilai rata-rata prestasi belajar minimal 75 .

Penelitian ini berfokus pada peningkatan hasil belajar siswa materi dimensi tiga di semester ganjil tahun pelajaran 2020-2021 dengan menerapkan e-learning menggunakan aplikasi Microsoft Teams dan Youtube khususnya siswa kelas XII MIPA-2 SMA Negeri 1 Jepara. Rumusan masalah dalam penelitian ini adalah sebagai berikut. (1) Apakah penerapan E-learning menggunakan aplikasi Microsoft Teams dan Youtube dapat meningkatkan motivasi belajar matematika materi dimensi tiga? (2) Apakah penerapan E-learning menggunakan aplikasi Microsoft Teams dan Youtube dapat meningkatkan prestasi belajar matematika materi dimensi tiga? (3) Apakah penerapan $E$ learning menggunakan aplikasi Microsoft Teams dan Youtube dapat meningkatkan motivasi dan prestasi belajar matematika materi dimensi tiga?

Adapun tujuan dari penelitian ini adalah (1) meningkatkan motivasi belajar matematika materi dimensi tiga, (2) meningkatkan prestasi belajar matematika materi dimensi tiga, dan (3) meningkatkan motivasi dan prestasi belajar matematika materi dimensi tiga.

\section{METODE PENELITIAN Setting Penelitian}

Penelitian ini termasuk dalam jenis penelitian tindakan kelas yang menekankan pada pengamatan motivasi dan prestasi belajar berupa aspek pengetahuan dan keterampilan berdasarkan kurikulum 2013. Penelitian ini dilakukan di SMA Negeri 1 Jepara Kabupaten Jepara, Jawa Tengah khususnya kelas XII MIPA-2 semester ganjil 2020-2021 pada bulan Juli sampai dengan bulan Oktober 2020.

\section{Teknik Pengumpulan Data}

Data diperoleh melalui teknik tes, observasi, dan dokumentasi. (1) Tes yang diberikan kepada siswa yaitu berupa tes tertulis daring dengan menggunakan microsoft form berbentuk soal pilihan ganda dengan tujuan untuk mengetahui prestasi belajar siswa pada materi dimensi tiga. Dari hasil tes yang diperoleh, didapat skor total untuk setiap siswa, kemudian dihitung nilai rata-rata kelas. (2) Observasi yang dimaksud berupa pengamatan terhadap proses pembelajaran yang dilakukan dengan memanfaatkan aplikasi microsoft teams dan youtube dengan tujuan untuk mengetahui bagaimana aktivitas siswa saat pembelajaran. Hasil observasi dihitung rata-rata pada tiap indikatornya kemudian dideskripsikan. (3) Dokumentasi berupa foto pelaksanaan penelitian.

\section{Teknik Analisis Data}

Analisis data menggunakan teknik analisis deskriptif komparatif untuk data kuantitatif, yakni dengan membandingkan prestasi belajar matematika kondisi awal (pra siklus) dan siklus I, memban- 
dingkan prestasi belajar matematika siklus I dan siklus II, serta membandingkan prestasi belajar matematika kondisi awal (pra siklus) dan kondisi akhir yang kemudian dilanjutkan refleksi, yakni menarik simpulan berdasarkan deskriptif komparatif, membuat ulasan berdasar simpulan, dan menentukan action plan atau tindak lanjut. Sedangkan untuk data kualitatif hasil pengamatan motivasi belajar matematika menggunakan analisis deskriptif kualitatif berdasarkan hasil observasi atau pengamatan dan refleksi dari tiap-tiap siklus, dengan membandingkan motivasi belajar matematika kondisi awal (pra siklus) dan siklus I, membandingkan motivasi belajar matematika siklus I dan siklus II, serta membandingkan motivasi belajar matematika kondisi awal (pra siklus) dan kondisi akhir. Kemudian dilanjutkan refleksi. Analisis data dilakukan secara bersamaan dan atau setelah pengumpulan data.

\section{Indikator Kinerja}

Penelitian tindakan kelas ini dikatakan berhasil jika: 1) sebagian besar (lebih dari 75\%) siswa kelas XII MIPA2 tahun 2020-2021 SMA Negeri 1 Jepara, motivasi belajar matematikanya meningkat, 2) sebagian besar (lebih dari 75\%) siswa kelas XII MIPA-2 tahun 2020-2021 SMA Negeri 1 Jepara, prestasi belajar matematikanya $\geq 70$ dan memiliki rata-rata minimal 75 , dan 3 ) sebagian besar (lebih dari 75\%) siswa kelas XII MIPA-2 tahun 2020-2021 SMA Negeri 1 Jepara, motivasi dan prestasi belajar matematikanya meningkat.

\section{HASIL DAN PEMBAHASAN}

Penelitian tindakan kelas dengan menerapkan e-learning menggunakan microsoft teams dan youtube materi dimensi tiga pada siswa kelas XII MIPA2 tahun pelajaran 2020-2021 menghasilkan hasil yang baik. Hal ini nampak dengan adanya perubahan dari kondisi awal ke siklus 1 dan dari siklus 1 ke siklus 2. Perubahan itu terlihat dari keaktifan siswa yang meningkat, jumlah siswa yang mencapai KKM meningkat, dan rata-rata prestasi belajar siswa meningkat. Agar lebih jelas, berikut adalah hasil dan pembahasan motivasi dan prestasi belajar siswa mulai kondisi awal, pasca siklus I, dan pasca siklus II.

\section{Motivasi Belajar}

Motivasi belajar matematika siswa XI MIPA-2 SMA Negeri 1 Jepara pada rentang waktu tengah semester hingga akhir semester genap tahun 2019-2020 dapat dilihat pada Tabel 1 .

Tabel 1. Motivasi belajar pada kondisi awal kelas XII MIPA-2 SMAN 1 Jepara

\begin{tabular}{clc}
\hline No & \multicolumn{1}{c}{ Aspek Amatan } & Kategori \\
\hline 1. & $\begin{array}{l}\text { Antusiasme siswa dalam } \\
\text { mengikuti PJJ. }\end{array}$ & Cukup \\
2. & $\begin{array}{l}\text { Respon atau sikap siswa } \\
\text { ketika dilaksanakan PJJ }\end{array}$ & Cukup \\
3. & $\begin{array}{l}\text { Respon siswa dalam } \\
\text { mempelajari materi pelajaran. }\end{array}$ & Cukup \\
4. & $\begin{array}{l}\text { Keaktifan siswa selama PJJ. } \\
\text { 5etertarikan siswa terhadap } \\
\text { model pembelajaran guru di- }\end{array}$ & Kurang \\
& Kurang \\
& $\begin{array}{l}\text { lihat dari proses penyelesaian } \\
\text { soal latihan yang diberikan. }\end{array}$ & \\
\hline
\end{tabular}

Dari Tabel 1, nampak bahwa motivasi belajar siswa kelas XII MIPA2 SMA Negeri 1 Jepara tahun 2020-2021 rendah. Terbukti hanya sebanyak 
$55,55 \%$ saja yang aktif dalam tanya jawab dan diskusi selama pembelajaran berlangsung. Sisanya sebanyak $44,45 \%$ siswa hanya sekedar absen dan tidak mengikuti pembelajaran hingga selesai.

Setelah dilakukan tindakan pada siklus I dan siklus II motivasi belajar matematika siswa khususnya pada materi dimensi tiga mengalami kenaikan seperti yang terlihat pada Gambar 2. Keaktifan ini dipicu adanya tuntutan dan tanggung jawab pada siswa untuk membentuk sebuah pengetahuan.

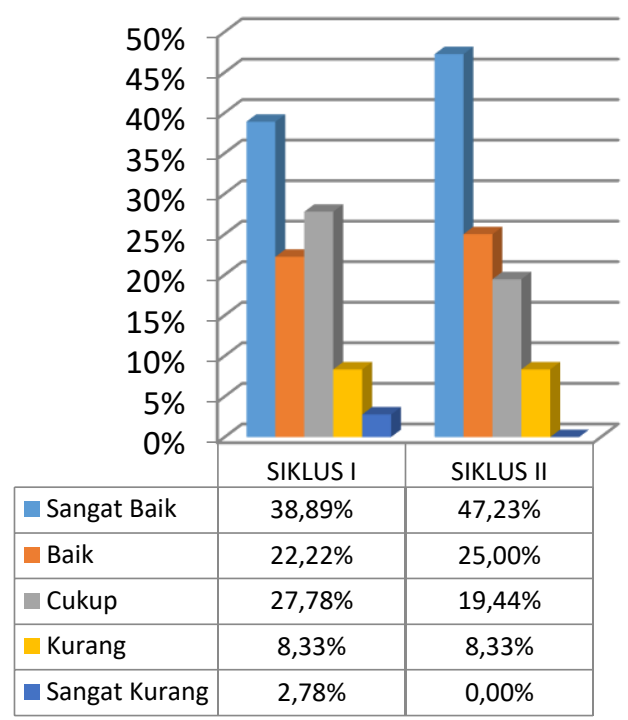

Gambar 2. Diagram Batang Keaktifan Siswa XII MIPA-2 SMAN 1 Jepara Tahun 2020-2021

Berdasarkan Gambar 2, nampak bahwa persentase keaktifan siswa dengan kategori sangat baik dan baik pada siklus I sebesar $61,11 \%$ atau sebanyak 22 dari 36 siswa, dan kategori cukup memiliki persentase jauh lebih besar dibanding kategori kurang dan sangat kurang. Sedangkan pada siklus II keaktifan siswa dengan kategori sangat baik dan baik meningkat menjadi $72,23 \%$ atau sebanyak 26 dari 36 siswa, dan kategori cukup memiliki juga memiliki persentase jauh lebih besar dibanding kategori kurang dan sangat kurang bahkan pada kategori sangat kurang 0\%. Dengan kata lain, persentase keaktifan dengan kategori sangat baik dan baik siswa XII MIPA-2 SMA Negeri 1 Jepara tahun 2020-2021 khususnya pada materi dimensi tiga sudah lebih baik dari sebelumnya (yaitu 55,55\%).

\section{Prestasi Belajar}

Persentase siswa XII MIPA-2 SMA Negeri 1 Jepara tahun 2020-2021 yang mencapai KKM (tuntas) pada materi dimensi tiga mengalami peningkatan dari siklus ke siklus seperti terlihat pada Gambar 3. Peningkatan ini bisa menunjukkan akan adanya pengaruh dari model pembelajaran yang digunakan dengan prestasi belajar.

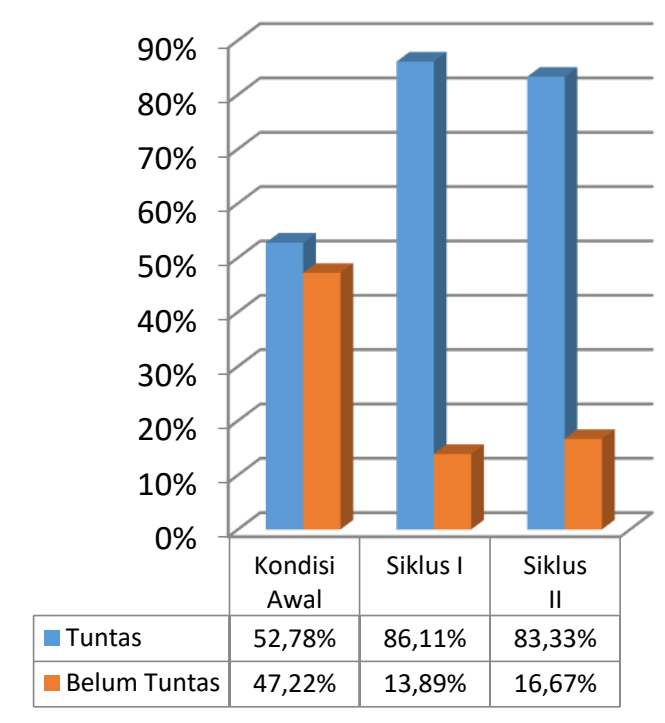

Gambar 3. Diagram Batang persentase Siswa yang Mencapai KKM

Selain persentase siswa yang mencapai KKM (tuntas) juga nilai ratarata siswa meningkat jika dibandingkan kondisi awal dengan pasca siklus II. Nilai rata-rata pada kondisi awal 65,05, sedangkan nilai rata-rata siswa pasca siklus II adalah 78,61. 


\section{Pembahasan}

Secara garis besar penelitian ini dilakukan karena melihat kondisi awal dimana motivasi dan prestasi belajar siswa pada saat mengikuti Pembelajaran Jarak Jauh (PJJ) rendah sehingga perlu dilakukan tindakan. Tindakan yang dilakukan adalah penerapan e-learning menggunakan microsoft teams dan youtube pada materi dimensi tiga. Pada siklus I peningkatan motivasi dan prestasi belajar siswa pada materi dimensi tiga dilakukan dengan membuat video pembelajaran tiap sub materi yang diupload di youtube dan link video disampaikan dalam kelas maya dengan menggunakan microsoft teams serta melakukan diskusi materi di kelas maya tersebut. Bentuk diskusi yang dilakukan adalah tanya jawab, dengan cara guru melemparkan satu per satu soal bentuk pilihan ganda untuk dijawab siswa pada rentang waktu tertentu Sedangkan pada siklus II peningkatan motivasi dan prestasi belajar siswa pada materi dimensi tiga dilakukan seperti pada siklus I dengan penyempurnaan video pembelajaran yang dibuat agar lebih menarik dan saat diskusi guru memberikan soal uraian kepada siswa dan siswa wajib menjawab soal tersebut dengan menunjukkan foto hasil pekerjaannya pada rentang waktu tertentu. Hasil motivasi dan prestasi belajar siswa yang diperoleh dapat diperhatikan pada Tabel 2 dan 3.

Hasil penelitian ini sejalan dengan penelitian yang dilakukan Numiek (2013) dengan judul "Keefektifan $E$ learning sebagai media pembelajaran (Studi evaluasi model pembelajaran $E$ learning SMK Telkom Sandhy Putra Purwokerto)" yang menyimpulkan bahwa pelaksanaan pembelajaran $E$ -

Tabel 2. Hasil Motivasi Belajar Siswa

\begin{tabular}{|c|c|c|c|c|}
\hline No & Kondisi Awal & Siklus I & Siklus II & Refleksi \\
\hline 1. & $\begin{array}{l}\text { Sebagian siswa } \\
\text { pasif. Terdapat } \\
44,45 \% \text { siswa yang } \\
\text { keaktifannya masih } \\
\text { dibawah baik. }\end{array}$ & $\begin{array}{l}\text { Sebagian siswa } \\
\text { pasif namun sudah } \\
\text { membaik. } \\
\text { Terdapat } 38,89 \% \\
\text { siswa yang } \\
\text { keaktifannya } \\
\text { masih di bawah } \\
\text { baik. }\end{array}$ & $\begin{array}{l}\text { Sebagian kecil } \\
\text { siswa pasif. } \\
\text { Terdapat } 27,77 \% \\
\text { siswa saja yang } \\
\text { keaktifannya } \\
\text { dibawah baik. }\end{array}$ & $\begin{array}{l}\text { Siswa yang pasif } \\
\text { berkurang dari sebagian } \\
\text { menjadi sebagian kecil. } \\
\text { Dari 44,45\% menjadi } \\
27,77 \% \text { atau berkurang } \\
\text { sebanyak } 6 \text { siswa. }\end{array}$ \\
\hline 2. & $\begin{array}{l}\text { Banyak siswa yang } \\
\text { tidak ikut } \\
\text { mengerjakan latihan } \\
\text { soal saat diskusi. } \\
\text { Rata-rata sebanyak } \\
>50 \% \text { siswa. }\end{array}$ & $\begin{array}{l}\text { Siswa yang tidak } \\
\text { ikut mengerjakan } \\
\text { latihan soal saat } \\
\text { diskusi cukup } \\
\text { banyak. Terdapat } \\
\text { sebanyak 36,11\% } \\
\text { siswa. }\end{array}$ & $\begin{array}{l}\text { Siswa yang tidak } \\
\text { ikut mengerjakan } \\
\text { latihan soal saat } \\
\text { diskusi sedikit. } \\
\text { Berkurang menjadi } \\
\text { 30,56\% siswa saja. }\end{array}$ & $\begin{array}{l}\text { Siswa yang tidak ikut } \\
\text { mengerjakan latihan soal } \\
\text { saat diskusi berkurang } \\
\text { dari banyak menjadi } \\
\text { sedikit, dari } \\
>50 \% \text { berkurang menjadi } \\
\text { 30,56\% siswa. }\end{array}$ \\
\hline 3. & $\begin{array}{l}\text { Motivasi siswa } \\
\text { dalam belajar } \\
\text { rendah, sebanyak > } \\
50 \% \text { siswa yang } \\
\text { motivasinya rendah. }\end{array}$ & $\begin{array}{l}\text { Motivasi siswa } \\
\text { dalam belajar } \\
\text { cukup tinggi, } \\
\text { sebanyak 63,33\% } \\
\text { siswa dalam } \\
\text { kategori } \\
\text { termotivasi dan } \\
\text { sangat termotivasi. }\end{array}$ & $\begin{array}{l}\text { Motivasi siswa } \\
\text { dalam belajar } \\
\text { tinggi. Terdapat } \\
75,56 \% \text { siswa } \\
\text { dalam kategori } \\
\text { termotivasi dan } \\
\text { sangat termotivasi. }\end{array}$ & $\begin{array}{l}\text { Motivasi siswa dalam } \\
\text { belajar meningkat dari } \\
\text { rendah menjadi tinggi, } \\
\text { meningkat dari kurang } \\
50 \% \text { menjadi } 75,56 \% \\
\text { atau meningkat sebanyak } \\
\text { lebih dari } 10 \text { siswa. }\end{array}$ \\
\hline
\end{tabular}


Tabel 3. Hasil Prestasi Belajar Siswa

\begin{tabular}{|c|c|c|c|}
\hline Kondisi Awal & Siklus I & Siklus II & Refleksi \\
\hline Nilai Ulangan & Nilai Ulangan & Nilai Ulangan & isi awal ke kond \\
\hline Harian pada & Harian pasca & Harian pasca & gkatan hasil \\
\hline kondisi awal: & Siklus I: & Siklus II: & signifikan \\
\hline - Nilai terendah & - Nilai terendah & - Nilai terendah & \\
\hline 40 & 40 & 50 & $\begin{array}{l}\text { - Nilai terendah naik } 25,00 \% \text { dari } 40 \\
\text { menjadi } 50 \text {. }\end{array}$ \\
\hline - Nilai te & - Nilai tertinggi & - Nilai te & - Nilai tertinggi tetap tidak \\
\hline $100(1$ & $100(4 \mathrm{sis}$ & 10 & $\begin{array}{l}\text { mengalami perubahan, namun jika } \\
\text { dilihat jumlah siswa yang } \\
\text { mendapat nilai tertinggi } \\
\text { mengalami kenaikan dari } 1 \text { siswa }\end{array}$ \\
\hline - Nilai rata-rata & - Nilai rata-rata & - Nilai rata-rata & ebanyak 3 siswa. \\
\hline 65,05 & 78,47 & 78,61 & ta naik $20,85 \%$ dari \\
\hline - Persentase & - Persentase & - Persent & njadi 78,61. \\
\hline ketu & ket & ket & - Persentase ketuntasan naik sangat \\
\hline $52,78 \%$ & $86,11 \%$ & $83,33 \%$ & $\begin{array}{l}\text { signifikan sebesar } 57,88 \% \text { yaitu } \\
\text { dari } 52,78 \% \text { menjadi } 83,33 \% \text {. }\end{array}$ \\
\hline
\end{tabular}

learning di SMK Telkom Sandhy Putra Purwokerrto mulai dari perencanaan pembelajaran, perancangan dan pembuatan materi, penyampaian pembelajaran, interaksi pembelajaran, dan evaluasi pelaksanaan pembelajaran cukup efektif dengan kecenderungan 77,27\% .

Dengan demikian berdasarkan pembahasan di atas dan hasil penelitian yang relevan, jelas diketahui sebagai berikut. (1) Melalui penerapan $E$ learning menggunakan aplikasi Microsoft Teams dan Youtube dapat meningkatkan motivasi belajar matematika materi dimensi tiga bagi siswa kelas XII MIPA-2 SMA Negeri 1 Jepara semester ganjil tahun 2020-2021 dari kondisi awal motivasi belajar matematika rendah ke kondisi akhir motivasi belajar matematika tinggi. (2) Melalui penerapan E-learning menggunakan aplikasi Microsoft Teams dan Youtube dapat meningkatkan prestasi belajar matematika materi dimensi tiga bagi siswa kelas XII MIPA-2 SMA Negeri 1 Jepara semester ganjil tahun 2020-2021 dari kondisi awal hanya memiliki nilai rata-rata 65,05 dengan persentase ketuntasan 52,78\% ke kondisi akhir yang memiliki nilai rata-rata 78,61 dengan persentase ketuntasan 83,33\%. Melalui penerapan E-learning menggunakan aplikasi Microsoft Teams dan Youtube dapat meningkatkan hasil motivasi dan prestasi belajar matematika materi dimensi tiga bagi siswa kelas XII MIPA-2 SMA Negeri 1 Jepara semester ganjil tahun 2020-2021.

\section{PENUTUP}

Berdasarkan hasil penelitian dan pembahasan diperoleh simpulan sebagai berikut. (1) Menurut teoritik dan empirik melalui penerapan E-learning menggunakan aplikasi Microsoft Teams dan Youtube dapat meningkatkan motivasi belajar matematika materi dimensi tiga bagi siswa kelas XII MIPA-2 SMA Negeri 1 Jepara semester ganjil tahun 2020-2021. (2) Menurut teoritik dan empirik melalui penerapan E-learning menggunakan aplikasi Microsoft Teams 
dan Youtube dapat meningkatkan prestasi belajar matematika materi dimensi tiga bagi siswa kelas XII MIPA2 SMA Negeri 1 Jepara semester ganjil tahun 2020-2021. (3) Menurut teoritik dan empirik melalui penerapan E-learning menggunakan aplikasi Microsoft Teams dan Youtube dapat meningkatkan hasil (motivasi dan prestasi) belajar matematika materi dimensi tiga bagi siswa kelas XII MIPA-2 SMA Negeri 1 Jepara semester ganjil tahun 2020-2021.

\section{DAFTAR PUSTAKA}

Ali, M. 2008. Guru dalam Proses Belajar Mengajar. Bandung: Sinar Baru Algesindo.

Catharina, T.A., at al. 2004. Psikologi Belajar. Semarang: UPT UNNES Press.

Cepi Riyana. 2019. Produksi Bahan Pembelajaran Berbasis Online. Tangerang Selatan: Universitas Terbuka.

Hakim Nasution, Andi. 1982. Landasan Matematika. Jakarta: Bharata Karya Aksara.

Harminingsih dan Santosa, Jaka. 2008. Penggunaan Strategi Pembelajaran Aktif Untuk Meningkatkan Efektifitas Pembelajaran Materi Logaritma Bagi Siswa Kelas X Program Akselerasi SMA Negeri 1 Surakarta Tahun Pelajaran 20082009. (Laporan PTK). Surakarta.

Hudojo, H.1988. Mengajar Belajar Matematika. Jakarta: Departemen Pendidikan dan Kebudayaan Direktorat Jendral Pendidikan Tinggi Proyek Pengembangan Lembaga Pendidikan Tenaga Kependidikan.
Kompasiana.com. 2016. Mengenal Youtube.

https://www.kompasiana.com/jesi calaurensia/mengenalyoutube_56cb0156c0afbd3218bb2 31e. Diakses 15 Juli 2020.

Numiek, S.H. 2013. Keefektifan Elearning sebagai Media Pembelajaran (Study Evaluasi Model Pembelajaran E-learning SMK Telkom Sandhy Putra Purwokerto): Jurnal Pendidikan Vokasi, Vol 3, Nomor 1, Februari 2013.

Sudjana, Nana. 1995. Penilaian Hasil Proses Belajar Mengajar. Bandung: PT Remaja Rosdakarya.

Suherman, E, at al. 2003. Strategi Pembelajaran Matematika Kontemporer (Common Textbook) edisi revisi. Bandung: Universitas Pendidikan Indonesia.

Tanaka, Y. 2012. "Lesson Study: Teori dan Praktik”. Makalah. Seminar Nasional Matematika di Universitas Negeri Semarang. Semarang, 13 Oktober.

Wikipedia. https://id.m.wikipedia.org/wiki/Y ouTube. Diakses 15 Juli 2015.

Wikipedia. https://id.m.wikipedia.org/wiki/Mi crosoft_Teams. Diakses 15 Juli 2020. 